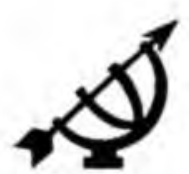

\title{
De/re/centring of subjective power
}

\author{
M.F. Heyns \\ Department of Philosophy \\ Potchefstroom University for $\mathrm{CHE}$ \\ POTCHEFSTROOM \\ E-mail: filmfh@puknet.puk.ac.za
}

\begin{abstract}
De/re/centring of subjective power

The centred self is the self in the centre of the universe with an underlying inner centre; that is, with one of the human abilities as the core power of the human being. I apply this distinction to the meta-psychological theories of Kenneth Gergen and Charles Taylor. Gergen liquidates the autonomous individual only to revert to a centring of the social side of the human condition. It is, according to Gergen, the postmodem condition of advanced transport and communication technologies that will be the end of the authentic self. Gergen rejects the possibility of resisting these postmodem technologies. The upshot of Gergen's socio-technological determinism is totalitarianism as well as agonism between individual and social aspects. Taylor seemingly steers away from centring one aspect. He nevertheless partially centres intention (interpretation). This gives his de/centring also an undecided and agonistic picture; that is a self in a never-ending confict with itself and surroundings. I suggest that only a re-centring of all human abilities will avert the final failure of the decentring of the centred self.
\end{abstract}

\section{Proem}

Postmodernism represents an uprising against the autonomous and objectifying modern individual who manipulates, dominates and even oppresses his natural environment, fellow humans and parts of itself this is the decentring of the centred self. My hunch is that the ontological positions of monism and dualism are at the root of the practice of centring because monism/dualism deify one or two aspects of the human condition which contributes to the tendency towards domination and oppression. The question is whether postmodern decentrings are able to identify and go beyond these constructs 


\section{What is de/centring?}

According to Gruber (1989:189-192) theorising is an activity with its locus in the subject and assumes that the "theory's involvement with the object is limited and relatively safe". Theorising "does not invent or manufacture the object ex nihilo". However, Gruber claims, this changes "dramatically when theory turns its attention to the subject itself". In this relation, subjects "contribute to the object so that the object as it is known bears the marks of the subject's activity". However, says Gruber, the subject usually "obscures its own role in manufacturing". It is here, he says that postmodern investigations "into the emergence of the subject" recover that "which theory tends to forget about itself". Now, Gruber too seems to have amnesia about the influence of the knowing subject on objects exterior to itself. Glas (1995:72), for instance, argues that one of the central problems of the classical view of the self is "the dialectic between me and the other" where "the other appears as an object opposite to me, to be appropriated, brought under control, and even dominated reflectively". This statement characterises the self as the objectifier, controller, dominator and even creator of anything outside itself, that is the whole extra-self universe. The postmodern notion of decentring indeed excels in this broader type of critique 1 .

Both the philosopher Charles Taylor and the psychologist Kenneth Gergen target especially the Romantic and Enlightenment versions of the centred self in their critique. According to Gergen (1992:60-61) we derive from Romanticism "our beliefs in a profound and stable center of identity - a center which harbored the vital spirit of life itself". However, Gergen argues, "for most people the romance with romanticism has cooled". The fascination with the "deep interior" is lost and we turned some time ago to "the demands and opportunities made possible by technology" that will give us the "mastery" to create "a Utopian world". For this we "needed conscious capability for keen observation and careful reason". Currently, however, not "only do soul, passion, and creativity become suspicious as centers of human existence, but so does rational thought and the efficient control of one's own actions". Taylor (1989a:461-463, 472-481) describes the demise of Enlightenment and Romantic views in more or less the same terms. However, where Gergen especially sees the demise of the modern self as a decentring of the Romantic self, Taylor tries rather to retain something Romantic and targets the Enlightenment self for his decentring. Taylor (1985a:132-135) detects a resistance to what he calls the "disengaged self" of modernism. The "disengaged self"

1 See Liberman (1989:127-129) and Schurmann (1979:167-174) for a genera description of this critique. 
is the self "whose defining aspirations, values and loyalties are determined out of himself, and not in reference to anything outside". This being sees the world around him simply as "raw material for his productive purposes". This model is challenged because of its "disastrous consequences, ecological and social". For Taylor this self is "inhuman" in the sense "that it cuts us off from the sources of community, creativity, and human feeling".

In my analysis I will use the following concept of centring and decentring Decentring, in general, attempts to uproot any foundational authority. According to Davis and Schleifer (1992:159-162) the centre that bases all other content, elements and concepts is seen by the classica philosophical tradition as an unchanging essence, epistemological immovable point as well as origin and point of control of all other beings in a particular system. If the self is centred, it originates and controls everything. Furthermore, this self usually has a power centre in itself The latter distinction means that we are dealing with a double centring and postmodern decentring of the self 2 . The image of a self in the centrecontrol of other beings can be called the inter-centred self. Decentring thus implies that heteronomous influences on the self and his behaviour are emphasised alongside the autonomous power of the self 3 . But the self is also seen to be centred in itself - that its power is contracted in one of its aspects, functions or capacities. This is the intra-centring of the self. A single human aspect is declared the true core and power of the human being and the other functions are disclosed as offshoots of this root $^{4}$. I will argue that the inter-centred self can in a sense be seen as the consequence of the more primal intra-centred self5. More precisely, what is seen as the intra-centred power of the self, determines the nature of the power of the inter-centred self. For instance, reason as the strong central capacity creates the illusion that the human being has the

2 Francke (1993:7) summarised the difference as follows: "In the metaphor of the 'decentring of the subject' the word 'of has two meanings, which are interconnected. First, it has the sense of a genetivus subjectivus: the subject itself has moved away from the centre. Secondly, in the sense of genetivus possessivus, the subject has lost its centre in itself".

3 I have encountered this concept of centring/decentring in the work of the following writers: Middleton and Walsh (1995:48), Sheridan (1980:92-93) and Mark Taylor (1987:44).

4 See Middleton and Walsh (1995:48) and Smith (1988:xxx) for the notion of the intracentred self

5 Mark Taylor (1987:44) and Sheridan (1980:92) hint at the primacy of the intra-centred self in the process of centring 
De/re/centring of subjectwe power

strength to be the centre of everything else by means of science and technology. Decentring in this instance means that the power of the self is no longer seen to be situated in a single power point inside the self. This is a very important correction because to situate subjective power in only one human aspect, to declare this the real self and to see it as the creator as well as the control centre of the universe, is a huge reduction of the plurality of human functions, as well as a distorted and inflated expectation of the power of a single human capacity. It is this thesis I will pursue in the thinking of both Gergen and Taylor.

\section{Centring of social relationships}

Gergen $(1991: 3,7,49,61,68,69,73,74)$ claims that the postmodern condition consists essentially of new technologies of mass communication and transport that make "it possible to sustain relationships either directly or indirectly - with an ever-expanding range of other persons". This will lead us to what he calls "a state of social saturation". This saturation will be the "acquisition of multiple and disparate potentials for being", which means "multiphrenia" is set in motion. Multiphrenia refers to the "splitting of the individual into a multiplicity of selfinvestments" which will be the end of the centred self.

However, we should probe deeper than the postmodern condition for Gergen's version of social determinism. Social determinism is, in Gergen's case, probably the heritage of an older generation of psychologists. It is, according to the environmentalist/behaviourist B.F. Skinner $(1972: 184,185,188,192,205,211)$, especially the exterior circumstances of a person that determines her behaviour. He rejects the traditional idea that "the autonomous agent" controls his environment. The human being should be seen as "controlled by the world around him, and in large part by other men". According to Clouser (1991:154-155) this social determinism sees the "needs of society as the standard for psychological normalcy". It forces us to "regard every leader, political or religious, who actually did achieve social superiority as abnormal". In fact, social determinism "rules out raising the question as to whether a society itself may be abnormal". These difficulties are even visible in Skinner's (1972:205-207) own terms. He asks whether the individual who is controlled by his social environment is "not then simply a victim". He agrees that "men have been victims" but adds that they also have "been victimizers". The human being may be controlled by his environment but "it is an environment which is almost wholly of his own making". We are dealing here with "a kind of gigantic exercise in self-control". Skinner nevertheless declares that there is "nothing inconsistent" about being both victim and victimizer. Not so, says Botha (1990:136); Skinner will 
not evade a paradox between subjective capabilities through the practice of science and being the victim of his cultural creations

The question is whether Gergen's social constructionism/constructivism will be able to evade these questionable side-effects of his predecessors. Gergen does not see the destruction of the self as a loss which causes Grodin (1992:186-187) to question his commitment to postmodernism. She says that if "postmodernism opens up to the potential for new ways of constructing the self, including ways that could incorporate models of autonomy, it was unclear why individuals wouldn't attempt to maintain a sense of a distinct self even in a relational context". This freedom, however, is not the kind of possibility Gergen has in mind when he advocates the liberties of the new lifestyle. According to Gergen (1991: 150-153;1992:62-63), the attempt to be true to an essence, an authentic self is a hang-up of modernism. The thoroughly postmodern person looks at multiphrenia and its technologies with the sense of "an enormous increase in the possibilities for human development". Every new relation is seen as "an open door to growth of expression, appreciation, and skill".

Wexter (1992:1752) questions Gergen's positive evaluation of the postmodern condition by claiming that people do not welcome the "dissolution of earlier social and self certainties". In fact, he says, "across class differences in cultural substance, everyday life is characterized by an evermore difficult struggle to establish a secure and integral selfidentity in the face of social contradiction and disintegration". Gergen (1991:199-201) however, is unrepentant. He recognises that beliefs in "a core self", "moral values" and "emotional capacities" remain "robust mainstays of Western culture". Nevertheless, he argues, "there is little reason to suspect that calls to defensive action will succeed". This belief is, once again, due to Gergen's deterministic social constructivist assumption that we simply do not have the inner resources to resist Gergen tries to make the postmodern condition responsible for this lack $\mathrm{He}$ argues that in "the longer run, though, the technologies giving rise to social saturation will be inescapable" (Gergen, 1991:200). The sense of totalitarian terror of this latter statement is too strong to ignore; we are all going to be the victims of the technologies of social saturation.

What went wrong in Gergen's postmodern decentring of the self? The decentring of the self, considering the repressive power and reductive unity of the traditional centred self, seems a necessary action. However, in radical decentrings it also has the dangerous potential of a full turn to a heteronomously determined self. In the act of decentring, the centre is not supposed to be simply substituted by the periphery. Taylor (1989a: 456) also criticises the current decentring of the self for creating a new centre; it is the "displacing of the center of interest onto language, or onto 
poetic transmutation itself, or even dissolving the self as usually conceived in favour of some new constellation". This danger is openly accepted by a fore-runner of postmodern thinking; structuralist anthropology. According to Bakker (1982:91) this view says kinship systems function as the originating subject. The individual human being is then the object on whom the formation is done. The individual subject has no substance and autonomy. This, however, is a suspicious description of the experience of human life. Humans indeed experience episodes of disempowerment but this need not be a kind of transcendental condition. Now, the tendency towards disempowerment of the self by means of reverse centring is also a constant danger in postmodern attempts, like that of Gergen, to explain behaviour. Gergen replaces the shallow rational self of modernism with a social condition that is supposed to be the supreme locus for human behaviour. At the end of this road, however, he also finds the terror of the self centred on one dimension of his condition.

A better end to the story of centring and decentring would have been a concept in which there is a simultaneous and equitable empowerment of the traditional self and non-self in the human domain (i.e. of all aspects of the human condition). Davis and Schleifer (1992:162-164) emphasise this when they point out that the postmodern deconstruction intends to upset hierarchies like that between autonomy and society. This may necessitate an initial stage in which a simple reversal of the centre and margin takes place. However, they say, the process should not stop here. In the second phase, the whole hierarchical relation must be done away with. It should end in an "undecidability"; in a free play of interpretation without truth and origin. The conclusion in the second phase, however, suspiciously sounds like a re-centring on the subjective power of interpretation - something I will get in better focus by discussing Taylor's thinking. A better perspective would be one in which the idea of a centred self is deconstructed but the questions, which have led to the centring, are still answered. The two questions that have caused the centring of the self are about the unity of the self and about the power of the self. The intra-centred self is an attempt to tell us how the self finds unity in itself as well as how the self maintains and affirms its position in the world. This, I believe, can still be done without resorting to a recentring of a single human aspect but yet empowering the entire human being.

In Gergen's case, it is not only the social aspect of human life that is centred. Combined with it, he centres a life-style. Gergen (1991:200) admits that his description of the postmodern lifestyle is limited to the "more urban, mobile, professional, affluent, and aspiring". This, he says is merely the vanguard of a global development of social saturation. 
Smith (1994:406) tries to give a sobering perspective by saying that "it is essential to remember that for the great majority of people, the existential perils that trouble the elite are eclipsed by real perils of survival and damage control". However, he also agrees that everyone will eventually "encounter the same threats to integral selfhood that now affect the affluent". Wexler (1992:1752), however, senses in Gergen's "communicatory and relational revolution" a "cultural arrogance - within a wider 'context' of a social structure of inequality and immiserization". Russell and Gaubatz (1995:389) discerned something related to this danger. It "may also be true that the material effects of these discourses first impact the elite" they say. But, they add, "postmodern discourses, like theoretical discourses in the past, come to affect individuals who, by design or otherwise, are kept dangerously unaware of the concerns of the elite". An example is architecture. During modernism architects "impose order on what was then perceived as the morally debilitating clutter and disorganizations of traditional cities". Their high-rise modernist buildings, however, disrupted the community lives of the poor in inner-cities. Postmodern architects plan to change this once again. In this case too, "postmodern theory, like modernism before it, may impose its greatest effects on those least familiar with its discourses". Thus, Gergen's deterministic social constructivist assumption has the danger of making us all the victims of a new inter-centring of Western yuppie style postmodernism.

Despite the strong totalitarianism in Gergen's thinking, there are also signs that he experiences the loss of the self in his thinking negatively. Gergen (1991:187-189) asks whether cynicism about truth claims should be the "necessary reaction to the loss of authenticity". This is a real temptation he says because it will give the postmodern person the sense of "self-contented superiority". However, he says, this is "a debilitating elixir, rendering one inactive and alienated". A strategy that tries to avoid cynicism is the attempt to "play with the truths of the day". We should act as if they are the truth but do not take terms like reality, authenticity, truth, etc. seriously. However, says Gergen (1991:193-194, 196), this playful attitude is also unsatisfying. It can be "demeaning" if play, wit or irony is your only reactions. You can make a fool of your intellectual opponents, but how will you respond to the death of a child or life in a cancer ward? You cannot, not take it seriously. He therefore contradicts his radical promotion of a non-self postmodernism by promoting "some form of compromise" between "the desire on the one hand to abandon the destructive potential of romanticist and modernist discourses, and on the other, to stop short of myth turned sour?". Gergen's synthesis is to "envision the possibility of serious play". It is as if some "transcendental truth" makes a claim on Gergen's sense of responsibility. The En- 


\section{De/re/centring of subjective power}

lightenment self with its rational and observational abilities that gains access to the "truth" returns, albeit vaguely, in Gergen6.

The return of an originating self also appears in another aspect of Gergen's thinking. Gergen (1999:7-10) claims that his questioning of the inner self portrays a "transformationist bias', that is, a continuous championing of the new, the expanded and the revolutionary as opposed to the accepted, the traditional, and secure". Psychology has to play a "significant role in augmenting or expanding the culture's resources". This means that the "scholar abandons the problematic role of describing 'what is the case', and sets out to forge languages favoring what may become". Underlying this sentiment, there is a reach for the self of Romanticism and its creative capacity to go beyond the current limits of the exterior environment. For Gergen the revolutionary nature of his postmodern viewpoint is what attracts him to it. However, this revolutionary or poetic activism also creates a paradox in his thinking between the end of the self and its Romantic return as the creative genius?.

\section{The centring of interpretation}

Gergen tries to decentre the self by declaring it dead due to the postmodern condition. This decentring, however, fails because Gergen recentre the self around a creative social aspect. The question now is whether Taylor will do a better job of decentring the self without dehumanising it. Promising is that Taylor is reknown for defending, to some extent, the inner self.

Taylor $(1985 a: 164,166,169-170,173-174)$ formulates his position in terms of the two horns of a dilemma that makes both body and mind the origins of action: On the one hand, he says, "there is no blanket argument to the inconceivability of mechanism"; that is an account "in terms of body chemistry and neurophysiology". On the other hand, however, Taylor also acknowledges that "common sense is alarmed by the prospect of a complete mechanistic account of behaviour". Surely, goes his argument, "our having goals is essentially involved in our being creatures capable of freedom and responsibility". Therefore, Taylor (1968:127; 1970a\&b:58, $75,94)$ asks, if both types - intentional and mechanistic explanations of

6 Gergen's concept of serious play is also for Smith (1994:408) and Wood (1992:425) an indication of an "ambivalence" or "an authentically conflicted person".

7 Referring to Foucault and Derrida, Taylor (1989b:482) also senses this paradox in postmodern thinking. 
behaviour - seem to apply, "which has the greater explanatory power". Taylor favours a balanced view where "mechanist and purposive explanations can co-exist". Taylor (1967:209) furthermore hierarchises (or centres) explanations of behaviour according to the situation to which it applies. In the case of certain pathological conditions, for instance, "the most fruitful explanation seems to lie on a physiological or biochemical level". However, there are other "ranges of behaviour" where intentional explanations are better. Taylor (1970a:57-58, 63, 72-73, 75-76) therefore argues that the answer about which explanation takes priority cannot be established a priori, but must be done "empirically".

Taylor is nevertheless well-known for his hermeneutical approach to the human sciences with a concomitant emphasis on the interpreting aspect of the human being. Thus, the question is whether he will be consistent in rejecting a fixed hierarchy in the explanation of behaviour. At certain times he gives a very strong sense of a fixed hierarchy in the explanation of behaviour. Taylor (1970a:72-74; 1980:62-63; 1985a:206-207) declares for instance that intentional and purposive behaviour are too complex to explain on a neurological level. He remarks that when any form of "higher" or more "complex behaviour" enters, no empirical observation is really going to convince us that the more basic level of explanation could be mechanistic

For some of his critics, Taylor is plainly an exponent of so-called agency theory, that is a position that centres the locus of the subject in the capacity to give intention to action (Scarrow, 1981:23-24; De Sousa, 1988:422-423). To understand this characterisation of Taylor one has to look into his explanation of the concept action. Taylor (1980:54-58) makes a distinction between humans as teleological systems and mere physical teleological systems. In physical systems tensions "would be measured in terms of force" and we "would not want to speak of 'action' here". In humans, we need "something more" to identify a movement as action. This "something more" will be found in the "direction' of an action" which can be identified "independently of its antecedent condition". Thus, about systems that act "it can be said that they direct their behaviour" which cannot be said about systems that merely move. Humans "can be considered agents" or "directors", to whom "responsibility can be attributed for their behaviour in a special sensen. This then assumes a centre of responsibility which is also the locus of interpretation. Taylor (1985a: 202) therefore declares that the "significance feature is at the centre of human life". Now, there does not seem to be any difference between a centre of responsibility and a centre of subjective power. They are each other's reverse sides. One can not take responsibility for something you have not originated or are able to do. Thus, although Taylor buys into the decentring discourse, and although he does not restrict the locus of 
behaviour to the intentional levels of behaviour, he simultaneously seems to elevate the intentional level above the rest of the human diversity.

Taylor's hierarchy between human aspects is underlined when he attempts to distinguish between things, animals and humans. For Taylor $(1985 a: 97-98,101-104,201 ; 1991: 263)$ "it is clear that persons are a sub-class of agents", which means that humans and animals share the feature of agency but not that of being a person. The difference between organisms (human beings and animals) on the one hand, and machines or things on the other, lies in the former being agents. Taylor (1980:6667 ; 1985a:98-99, 102, 192-197, 201; 1988:450-451; 1991:259-264) locates this agency in the capacity to "attribute significance to things". Furthermore, this fact that "things matter to agents" creates in them "purposes, desires, aversions". To Taylor, this view supplies the fundamental distinction between agents (human and animal) and things he is looking for. Machines can have only "derivative purpose"; outside of the designer or user's context; they do not have any purposes of themselves, whereas in the case of humans and animals we can "ascribe action to them and distinguish, in their behaviour, between action and movement". Organisms are distinguished by their ability to interpret their inner and outer contexts which gives them the power to posit their own goals and act autonomously. A thing, on the other hand, is fully heteronomously determined.

A further problem is to distinguish between a human person and an animal agent. The difference Taylor sees between things and organisms is about the difference between autonomy and heteronomy; autonomous power is vested in the interpretative capacity that is not inside beings without it. Taylor extends this difference also to the difference between humans and animals. Because the significance feature, and thus having purposes, belong to both, Taylor (1980:70-71; 1985a:201) cannot make a clear difference between humans and animals. He nevertheless operates also with a hierarchical continuum. At the lower end are "beetles" for whom "such concepts as 'action', and even more, 'desire' .. seem less and less appropriate". At the other end of the continuum are humans and higher animals that are not only teleological systems but systems that are also purposive in nature. The only avenue of distinction between animals and human beings for Taylor (1985a:102; 1991:263264 ) is therefore to look for "matters of significance for human beings which are peculiarly human". But then the problem is still to define the "peculiarly human". This he finds in "matters of pride, shame, moral goodness, evil, dignity, the sense of worth, the various human forms of love, and so on". However, it is questionable to imply that animals are totally incapable of significances like pride, shame, love etc. 
Taylor, nevertheless, has another difference in mind: Humans have a stronger ability for attributing significance or meaning than animals. For Taylor (1980:64-65, 67-70) "self-avowal makes an enormous difference" in the sense that "human beings are conscious of what they are reacting to in the way that animals are not". A human being can, for instance, fear a lion because he has picked out the lion "as" something to be feared. In another situation, for instance in a game park, the lion is not something to be feared but an object of entertainment or enjoyment. For an antelope the lion is simply something to fear, he does not think of the lion "as" something to fear. This then is "a reduced form of consciousness". This means that the "behaviour of animals can be accounted for simply by a set of species laws, a number of natural tendencies towards certain types of activity". In humans, on the other hand, "a factor of variance is introduced" because their search for goals "is dependent on the idea they have of these goals, the way they describe them to themselves"

The underlying tendency in Taylor's distinction between humans and animals is to give humans a stronger interpretative ability. This stronger intra-ability also seems to give humans more power in the world in which they find themselves. However, it seems as if Taylor cannot progress to a qualitative difference between humans and animals. Humans are merely more developed interpreters than animals ${ }^{8}$. Now, Taylor's struggle to firstly allocate the significance aspect exclusively to organisms and then to try and make it stronger in human agents, betrays an elevation of the significance aspect to the prime human ability.

However, we should be subtler and ask whether his centring of significance is indeed dangerous. I have closed my analysis of Gergen with the remark that for an advocate of selflessness he paradoxically assumes a concept of originating subjectivity. This, says Taylor $(1985 \mathrm{~b}: 173-174 ; 1989 \mathrm{a}: 456)$, is a peculiar trait of twentieth century modernism: On the one hand, it "has gone more inward" than Romanticism, "even to celebrate subjectivity". But, simultaneously it has profoundly decentred the subject. According to Taylor, this double feature indicates a simultaneous "slide to subjectivism and an antisubjectivist thrust". From this paradox he infers that there "must be something between total subjectivism, on the one hand, holding that there are no undesigned patterns in history, and the strange Schopenhauerism-without-the-will" of postmodernists, on the other hand. Therefore, he says, to "give an absolute priority to the structure makes exactly higher animals other than men to whom teleological discourse seems to apply as well". 
as little sense as the equal and opposite error of subjectivism, which gave absolute priority to action as a kind of total beginning".

This analysis of current tendencies translates also into a more personal view for Taylor. Taylor (1985a:103, 189; 1991:261, 264-366) indeed talks of a "transformation" of significances which means the person creates himself with his self-interpretations. This implies that what "we are at any moment is, one might say, partly constituted by our self-understanding". important in the latter statement is his use of the word "partly". It would be difficult to convince Taylor to reject his deep-rooted affinity with the Romantic centring of subjective power in the creatively interpreting ability. However, it is at the same time clear that he is not an unabashed centrist. Human creative power, although the trademark of the truly human, is only partial.

The background to his use of the word "partly" lies in his description of current thinking. Modern (i.e. current) thinkers, Taylor (1989a:441-446, 456-461) says, are, like the Romantics, opposed to the Enlightenment's instrumental reason that is "shallow and debased". Romanticism countered this with a return to nature and feeling. However, the current return to nature is not totally what it was before. Although nature is still seen as a power which "comes to expression in things", it is no longer a "'spiritual source of good but a wild, and blind drive". This, however, does not compel us to capitulate before shallowness; a return to interiority by means of the inner powers of the self is still possible. The "lived experience or creative activity underlying our awareness of the world" has to be recovered - it is "through the articulations of the creative imagination that the wild drive is tapped and transmuted into beauty". The notion of "wild and blind" nature can be seen as a restriction to subjective powers; that the celebration of our own powers of creativity will not be unlimited

Indeed, this undecided position ${ }^{9}$ is not unfamiliar to the current decentring of the self. Derrida $(1991: 96-97,103-105,109)$ for instance claims that his deconstruction of the self does not "sought to 'liquidate" the subject. What he questions is predicates like "identity to self, positionality, property, personality, ego, consciousness, will intentionality, freedom, humanity, etc.". In its place he asks for a discussion in which the subject is to be "reinterpreted, displaced, decentered, re-inscribed". He will therefore especially endorse a concept of the self that "would no

9 This is also Lemmens' (1994:126) view: "Schipperend tussen appreciatie en kritische afstandelijkheid poogt Taylor nu aan te tonen hoe de belangrijkste morele tradities van de ambigue zelfinterpretatie van het hedendaagse zelf inaugureren" 
longer include the figure of mastery of self, of adequation to self, center and origin of the world, etc." 10 .

It is this tension Taylor observes between self-creation and the current sense of the aggressiveness of the world. It is a tension that can be found in graphic detail in Rorty's ponderings of the self-creative acts of human beings. Rorty (1993:30-33, 35-36) admits that his idea that "the mind is a poetry-making faculty" may seem to be a return to the "idea of an intrinsic human nature ${ }^{n}$ - something he would try to escape from Rorty nevertheless and paradoxically so"11, affirms the notion that "shared by all of us" is "a faculty for creating". He even sees it as "the distinctively human, as opposed to animal, portion of each human life". Rorty (1993:27-29) sees self-creation as an attempt to escape from "inherited descriptions". Rorty (1993:40-43) nevertheless feels the need to mitigate the "strong poet". He can in the end not avoid seeing the self as also dependent on a context that she does not fully control. This tempered claim of the self's capabilities is not only true of its relation to other selves but also of the relation to the world. This is where the theme of victimisation announces itself most explicitly in Rorty. Although Rorty (1993:40) argues that the world should be "de-divinized" it can still "have power over us - for example, the power to kill us". How do we counter this power? According to Rorty the only stance we can adopt is "to recognize contingency and pain" and to still try to remake the world because "this is the only sort of power over the world which we can hope to have".

For Taylor the human being is not a total given, her capacity for selfinterpretation assumes self-creative acts. But, like an important strain in current thinking, Taylor acknowledges the violent limits to this selfcreation. Taylor therefore also subverts the centrism of self-creative power with the addition of the concept "partly". However, to be partially detached from the centrist image is also to be partially part of it.

10 This decentring of the self without liquidating it, bespeaks an underlying tension. The background to this is the struggle against metaphysics. Deconstruction therefore sees itself as an attempt to cause disruptions and displacements. It does not intend fixed conclusions but wants to be "aporetic", to bring about paradoxes without solutions (Van Peursen, 1995:42, 45-46). The goal of deconstruction is to indicate the conceptual distinctions of the author and his incoherent use of these concepts. The standards and criteria of the text itself are therefore used to disturb and uproot the text; the text is failing according to its own criteria (Sarup, 1989:37).

11 Hollis (1991:244-245) also finds Rorty's rejection of the centred self but affirmation of the "poetic" self, contradictory. 


\section{Resolution}

Current thinking on the subjective power of the self has moved into an irredeemably paradoxical position. This position puts the self in the situation of being both victimised and victimiser. This seems to be Gergen's and also Taylor's viewpoint. The aim is to curb the overrating of the power of the self and to transform it to a more realistic perspective. Gergen's, but especially Taylor's view sometimes leaves the popular postmodern impression that we are left with a view of the self in conflict with himself and his environment. Part of the reason for this is probably the partial centring of the self in his creative capacity that resides in either interpretation or social construction (which is society's version of interpretation). These two thinkers do not take care to disperse agency power to more than these capacities. A centred self gives an immanent driving force to the universe as holistic system. Such an immanentism will necessarily lead to a contest between aspects of this system for leadership. Therefore, if reality tries to enforce "wild and blind" meaning, it will clash with our attempt to give human meaning to life. In a noncentred systemic view on the other hand, the self should be part of a broader universe of meaning and the reason for agonism will fade.

Because a fixed centring gives a reductive and impoverished image of the human being, the decentring of the traditional view of the self is a useful and necessary exercise. However, a one-sided focus on this critique has the effect of repressing the human origin of actions and behaviour, albeit only a partial origin. In other words, after the decentring of the self, we need a re-centring of the self to empower and unify the postmodern fragmented and disempowered self. The decentring of the self indeed implies an aporetic or agonistic strategy in which both autonomous and heteronomous powers are uphold12. We will therefore have to accommodate the issues that initially have given life to the classical self. Here we should especially deal with the quest for an agent who can be responsible for historical, moral and knowing actions. The oscillation between the contradictions of humanism and anti-humanism should show the way to a more fundamental task: We should, with the gained knowledge of the decentring of the self, once again try to give a transcendental critique of the self; that is, we should once again try to formulate the conditions for a coherent and responsible human existence. The aborted death of the self is essentially a cry for an acceptself, but to a recentring of self in relation of love in community" 
able reformulation of the conditions for being human as empowered identity.

The empowerment of all human aspects will assume a re-centring of these aspects. It is obvious that we cannot embark on a simultaneous recentring of all aspects in all situations. This means the situation will to some extent determine the re-centring of a relevant human aspect. This concept is (partly) akin to what Rorty interprets Freud to have done. In the process of de-divining the self, Rorty (1993:32-33) argues, Freud "makes it possible for us to see science and poetry, genius and psychosis - and, most importantly, morality and prudence - not as products of distinct faculties but as alternative modes of adaptation". To this we can add Oksenberg Rorty's and Wong's (1990:19-20) perspective that a "person's identity is constituted by a configuration of central traits" and that the "question of whether a trait is part of a person's identity generally has no simple and univocal answer; it is contextually subscripted to one or more dimensions of centrality". Identity traits and human capabilities are coping skills. If the scientific situation is considered for instance, the analytical capacity of the scientist needs to be in the centre of his behaviour. Other capacities are then, in various degrees, on the periphery. Something like the emotions of the scientist will clearly be a lot further from this centre. But in a situation where expression of love is called for, the centre will be filled with emotion and cool analysis will have to take a lesser position.

We can thus state as principle that a moderate return of the initiating self (agency) should assume agency in a plurality of aspects. At the same time, however, this plurality of agency-functions should be exercised in coherence and inter-dependence with one another, as well as the environment and "other" of the self (as coherence of agency aspects). This picture of the coherence of a plurality has the double advantage of a decentring and recentring. It decentres in the sense that a systemic view of the relation between aspects is created. This means aspects define one another's power; the subjective power of aspects is relative to one another. Coherence nevertheless also makes the recentring of power possible in the sense that those aspects that were decentred because of the totalitarian centring of one aspect, are empowered again.

\section{Bibliography}

BAKKER, R. 1982. Wijsgerige antropologie van de twintigste eeuw Assen : Van Gorcum.

BOTHA, ME. 1990. Metateoretiese perspektiewe op die sosiale wetenskappe Potchefstroom : $\mathrm{PU}$ vir $\mathrm{CHO}$

CLOUSER, R.A. 1991. The myth of religious neutrality - an essay on the hidden role of religious belief in theories. Notre Dame: University of Notre Dame Press. 
DAVIS, R.C. \& SCHLEIFER, R. 1992. Criticism and culture: the role of critique in modern literary theory. Burnt Mill, Harlow, Essex: Longman.

DE SOUSA, R. 1988. Seizing the hedgehog by the tail: Taylor on the self and agency. Canadian Journal of Philosophy, 18(3):421-432.

DERRIDA, J. 1991. "Eating well", or the calculation of the subject: an interview with Jacques Derrida. (In Cadava, E., Connor, P., Nancy, J-L., eds. Who comes after the subject. New York : Routledge. p. 96-119.)

FRANCKE, S. 1993. Room for the other - about the de-centred subject. Unpublished paper delivered at the Institute for Christian Studies, Toronto, Canada.

GERGEN, K.J. 1991. The saturated self. United States of America : BasicBooks (a division of HarperCollins Publishers)

GERGEN, K.J. 1992. The decline and fall of personality. Psychology Today, 25:5963.

GERGEN, K J. 1999 The place of the psyche in a constructed world. (Internet version, 21 pages: http://uww swarthmore.edu/SocSci/kgergen1/manu.html).

GLAS, G. 1995. Ego, self, and the body - an assessment of Dooyeweerd's philosophical anthropology (In Griffioen, S. \& Balk, B.M., eds. Christian philosophy at the close of the twentieth century - assessment and perspective. Kampen : Uitgeverij Kok. p. 67-78.)

GRODIN, D 1992. Review of 'The saturated self - dilemmas of identity in contemporary life'. Joumal of Communication, 42:185-187.

GRUBER, D.F. 1989. Foucault and theory: genealogical critiques of the subject. (In Dallery, AB. \& Scott, CE., eds. The question of the other - essays in contemporary continental philosophy. Albany, N.Y. : State University of New York Press. p. 189-196.)

HOLLIS, M. 1991. The poetics of personhood (/n Malachowski, A.R., ed Reading Rorty - critical responses to 'Philosophy and the Mirror of Nature' (and beyond). Oxford: Basil Blackwell. p. 244-256.)

LANDESMAN, C. 1966. The new dualism in the philosophy of mind The Review of Metaphysics, 19:329-345.

LEMMENS, $W$. 1994. Zelf en gemeenschap: de paradox van die moderne identiteit volgens Charles Taylor. Tijdschrift voor Filosofie, 56(1):117-133.

LIBERMAN, K. 1989. Decentering the self: two perspectives from philosophical anthropology. (In Dallery, A.B. \& Scott, C.E., eds. The question of the other essays in contemporary continental philosophy. Albany, N.Y. : State University of New York Press. p. 127-142.)

MIDDLETON, J R. \& WALSH, B.J. 1995. Truth is stranger than it used to be - biblical faith in a postmodern age. Downers Grove, Illinois : InterVarsity Press.

OKSENBERG RORTY, A. \& WONG, D. 1990. Aspects of identity and agency. (In Flanagan, O. \& Oksenberg Rorty, A., eds. Identity, character, and morality essays in moral psychology. Cambridge, Massachusetts : MIT Press. p. 19-36.)

OLTHUIS, J.H. 1993. Crossing the threshold: sojourning together in the wild spaces of love. (Unpublished 'Presidential Address to the Canadian Theological Society' p. 1-36.)

RORTY, R. 1993. Contingency, irony, and solidarity. Cambridge : Cambridge University Press

RUSSELL, R.L. \& GAUBATZ, M.D. 1995. Contested affinities: Reaction to Gergen's and Smith's postmodernisms. American Psychologist, 50:389-390.

SARUP, M. 1989. An introductory guide to post-structuralism and postmodernism. Athens, Georgia : University of Georgia Press. 
M.F. Heyns

SCARROW, D. 1981. The causality of reasons: a survey of some recent developments in the mind-body problem. Metaphilosophy, 12(1):13-30.

SCHÜRMANN, R. 1979. Anti-humanism - reflections of the turn towards the postmodern epoch. Man and World, 12(2):160-177.

SHERIDAN, A. 1980. Michel Foucault - the will to truth. London : Tavistock Publications.

SKINNER, B.F. 1972. Beyond freedom and dignity. London : Jonathan Cape.

SMITH, M.B. 1994. Selfhood at risk - postmodern perils and the perils of postmodernism. American Psychologist, 49:405-411.

SMITH, P. 1988. Discerning the subject. Minneapolis : University of Minnesota Press.

TAYLOR, C. 1967. Mind-body identity, a side issue? The Philosophical Review, 76:201-213

TAYLOR, C. 1968. A reply to Margolis. Inquiry, 11:124-128

TAYLOR, C. 1970a. The explanation of purposive behaviour. (/n Borger, R. \& Cioffi, F., eds. Explanation in the behavioural sciences. Cambridge : Cambridge University Press. p. 49-79.)

TAYLOR, C. 1970b. Reply to Borger. (In Borger, R. \& Cioffi, F., eds. Explanation in the behavioural sciences. Cambridge : Cambridge University Press. p. 89-95.)

TAYLOR, C. 1980. The explanation of behaviour. London : Routledge \& Kegan Paul.

TAYLOR, C. 1985a. Philosophical Papers I: Human agency and language Cambridge : Cambridge University Press.

TAYLOR, C. 1985b. Philosophical Papers II: Philosophy and the Human Sciences Cambridge : Cambridge University Press.

TAYLOR, C. 1988. Reply to de Sousa and Davis. Canadian Journal of Philosophy, 18(3):449-458

TAYLOR, C. 1989a. Sources of the self - the making of the modern identity Cambridge : Cambridge University Press.

TAYLOR, C. 1989b. Overcoming epistemology. (In Baynes, K., Bohman, J. \& McCarthy, T. After philosophy; end or transformation? Cambridge, Massachusetts : MIT Press. p. 464-488.)

TAYLOR, C. 1991. The person. (In Carrithers, M. Collins, S. \& Lukes, S., eds. The category of the person. Cambridge : Cambridge University Press. p. 257-281.)

TAYLOR, M.C. 1987. Erring - a postmodern a/theology. Chicago : The University of Chicago Press.

VAN PEURSEN, C.A. 1995. Na het postmodernisme - van metafysica tot filosofisch surrealisme. Kampen : Kok Agora.

WEXLER, P. 1992. Review of 'The saturated self - dilemmas of identity in contemporary life'. American Journal of Sociology, 97:1751-1752.

WOOD, J.T. 1992. Truth in trouble: mind, self, and relationships in postmodernity Communication Quarterly, 40(4) 422-428.

Key concepts:

agency theory

Charles Taylor

decentring of the self

interpretation

Kenneth J. Gergen

social constructivism

postmodern self

Koers 65(1) 2000:77-94 
Delre/centring of subjective power

\section{Kernbegrippe}

agent-teorie

Charles Taylor

desentrering van die self

interpretasie

Kenneth J. Gergen

sosiale konstruktiwisme

postmoderne self 